\title{
Author Correction: Task-dependent representations of stimulus and choice in mouse parietal cortex
}

\author{
Gerald N. Pho (10) 1,2,3, Michael J. Goard (1) 1,2,4,5, Jonathan Woodson 1,2, Benjamin Crawford ${ }^{1,2}$ \& Mriganka Sur ${ }^{1,2}$
}

Correction to: Nature Communications; https://doi.org/10.1038/s41467-018-05012-y; published online 03 July 2018

In the original version of this Article, the Acknowledgements section was inadvertently omitted. This has now been corrected in both the PDF and HTML versions of the Article.

Published online: 18 January 2019

\begin{abstract}
(c) (i) Open Access This article is licensed under a Creative Commons Attribution 4.0 International License, which permits use, sharing, adaptation, distribution and reproduction in any medium or format, as long as you give appropriate credit to the original author(s) and the source, provide a link to the Creative Commons license, and indicate if changes were made. The images or other third party material in this article are included in the article's Creative Commons license, unless indicated otherwise in a credit line to the material. If material is not included in the article's Creative Commons license and your intended use is not permitted by statutory regulation or exceeds the permitted use, you will need to obtain permission directly from the copyright holder. To view a copy of this license, visit http://creativecommons.org/licenses/by/4.0/.
\end{abstract}

(C) The Author(s) 2019

\footnotetext{
${ }^{1}$ Department of Brain and Cognitive Sciences, Massachusetts Institute of Technology, Cambridge, MA 02139, USA. ${ }^{2}$ Picower Institute for Learning and Memory, Massachusetts Institute of Technology, Cambridge, MA 02139, USA. ${ }^{3}$ Department of Organismic and Evolutionary Biology, Harvard University, Cambridge, MA 02138, USA. ${ }^{4}$ Department of Molecular, Cellular, and Developmental Biology, University of California, Santa Barbara, Santa Barbara, CA 93106, USA. ${ }^{5}$ Department of Psychological \& Brain Sciences, University of California, Santa Barbara, Santa Barbara, CA 93106, USA. Correspondence and requests for materials should be addressed to M.S. (email: msur@mit.edu)
} 